\title{
Upaya Peningkatan Penerapan Budaya Keselamatan Pasien di Rumah Sakit
}

\author{
Najla Asyah Syafawani Lubis/191101010 \\ najlaasyahsyafawani@gmail.com
}

\section{Latar Belakang}

Keselamatan menjadi isu global dan terangkum dalam 5 isu yang terkait di rumah sakit yaitu keselamatan pasien, keselamatan pekerja atau petugas kesehatan, keselamatan bangunan dan peralatan di rumah sakit yang bisa berdampak terhadap keselamatan pasien dan petugas. Kecamatan lingkungan yang berdampak terhadap pencemaran lingkungan dan keselamatan bisnis rumah sakit yang terkait dengan kelangsungan rumah sakit. Keselamatan pasien merupakan prioritas utama untuk dilaksanakannya terkait dengan isu mutu dan Citra perumahsakitan. Gerakan penting Septi keselamatan pasien telah menjadi spirit dalam pelayanan rumah sakit di seluruh dunia tidak hanya rumah sakit di negara maju yang menerapkan keselamatan pasien untuk menjamin mutu pelayanan, tetapi juga rumah sakit di negara berkembang seperti di Indonesia (Depkes, 2006).

Pada saat ini upaya untuk meningkatkan mutu pelayanan dan meningkatkan upaya keselamatan pasien di rumah sakit sudah merupakan sebuah gerakan universal. Berbagai negara maju bahkan telah menggeser paradigma quality ke arah paradigma baru quality safety yang mengandung arti tidak hanya meningkatkan mutu pelayanan, namun yang lebih penting adalah menjaga keselamatan pasien secara konsisten dan terus-menerus. Keselamatan safety telah menjadi isu global termasuk juga untuk rumah sakit. Terdapat lima isu penting yang terkait dengan keselamatan safety di rumah sakit dan keselamatan pasien safety merupakan salah satunya. Kelima aspek keselamatan tersebut sangatlah penting untuk dilaksanakan di setiap rumah sakit. Namun harus diakui kegiatan institusi Rumah Sakit dapat berjalan Apabila ada pasien, sehingga keselamatan pasien merupakan prioritas utama untuk dilaksanakan dan hal tersebut terkait dengan isu. Mutu dan Citra rumah sakit (Mandriani, 2019).

Kementerian Kesehatan Republik Indonesia telah mengeluarkan peraturan Menteri Kesehatan No 11 tahun 2017 tentang keselamatan pasien di rumah sakit. peraturan ini menjadi tonggak utama operasionalisasi keselamatan pasien di rumah sakit seluruh Indonesia. Banyak rumah sakit 
di Indonesia yang telah berupaya membangun dan mengembangkan keselamatan pasien, namun upaya tersebut dilaksanakan berdasarkan pemahaman manajemen terhadap keselamatan pasien. Peraturan menteri ini memberikan panduan bagi manajemen Rumah Sakit agar dapat menjalankan spirit keselamatan pasien secara utuh.

Keselamatan pasien adalah suatu sistem yang membuat asuhan pasien lebih aman, meliputi asesmen resiko, Identifikasi dan pengelolaan risiko pasien, pelaporan dan analisis insiden, kemampuan belajar dari insiden dan tindak lanjutnya, serta implementasi solusi untuk meminimalkan timbulnya risiko dan mencegah terjadinya Cedera yang disebabkan oleh kesalahan akibat melaksanakan suatu tindakan atau tidak mengambil tindakan yang seharusnya diambil. Insiden keselamatan pasien adalah Setiap kejadian yang tidak disengaja dan kondisi yang mengakibatkan atau berpotensi mengakibatkan Cedera yang dapat dicegah pada pasien.

Keselamatan pasien dipengaruhi oleh Bagaimana individu dan sistem yang berjalan di dalam organisasi tersebut. Sehingga harus dilakukan pendekatan secara personal atau individu maupun sistem manajemen didalam institusi tersebut. Budaya keselamatan di berbagai industri berkembang sangat pesat. Angka kecelakaan kerja menurun karena didukung oleh kesadaran akan arti pentingnya nilai keselamatan dalam organisasi. Sebuah penelitian mengungkapkan bahwa keberhasilan pelaksanaan program keselamatan pasien oleh petugas Rumah Sakit dipengaruhi oleh beberapa hal Salah satunya adalah budaya keselamatan pasien. Oleh karena itu perlu ada nya peningkatan penerapan budaya keselamatan pasien di rumah sakit.

\section{Metode}

Rancangan penugasan kajian ini menggunakan metode literatur review. Dimana metode ini dapat menyelesaikan suatu masalah dengan mengumpulkan data, menganalisa, membandingkan sehingga dapat menentukan pengambilan keputusan dalam masalah tersebut yang berdasarkan dari penjelasan sumber dan referensi yaitu berupa jurnal, ebook atau buku teks.

\section{Hasil}

Berdasarkan hasil penelitian Ultaria, 2017. Menunjukkan bahwa penerapan budaya pasien di rumah sakit tergolong sedang dengan persentase $71 \%$ terhadap 72 responden. Pada penelitian Puji Lestari 2013, menunjukkan bahwa dari 75 responden, 37 responden (49,3\%) termasuk 
dalam penerapan budaya keselamatan pasien yang rendah dan 38 responden $(50,7 \%)$ termasuk dalam penerapan budaya pasien yang tinggi. Upaya yang dapat dilakukan agar budaya keselamatan dapat meningkat antara lain adalah dengan meningkatkan motivasi perawat dan mengoptimalkan peran kepala ruangan. Pada penelitian Nivalinda 2013, motivasi perawat terhadap penerapan budaya keselamatan pasien menunjukkan bahwa sebagian besar responden yaitu sejumlah 57 responden (53\%) mempunyai motivasi rendah.

Pada penelitian Juniarti 2018, dalam melakukan upaya peningkatan mutu dan keselamatan pasien dirumah sakit, Rumah Sakit Umum daerah provinsi Nusa Tenggara Barat masih memiliki beberapa kendala. Kendala tersebut salah satunya yaitu masih kurangnya kesadaran dan keterbukaan dari staf atau pegawai rumah sakit untuk melaporkan Setiap kejadian yang terjadi saat proses pemeriksaan terhadap pasien karena mereka menganggap hal itu biasa terjadi serta bukan hal yang perlu dibesar-besarkan dan mereka Langsung bisa menangani hal tersebut, sehingga budaya pelaporan insiden keselamatan pasien di fasilitas pelayanan kesehatan tersebut masih kurang karena belum semua staf atau pegawai rumah sakit melaporkan jika sewaktuwaktu ada insiden keselamatan pasien.

Laporan insiden keselamatan pasien di Indonesia oleh komite keselamatan pasien di rumah sakit Indonesia berdasarkan provinsi pada Kuartal 1 periode januari sampai April 2010 ditemukan provinsi Jawa Barat menempati urutan tertinggi sebesar 33,33\% diantara provinsi lainnya (Banten 20\%, Jawa Tengah 20\%, DKI Jakarta 16, 67\%, Bali 6,67\%, Jawa Timur 3,3 7\%) (komite keselamatan pasien RS, 2008).

Berdasarkan data hasil penelitian terkait keselamatan pasien di Indonesia yang telah dilakukan oleh Nurmalia dan Nivalinda, 2016. Pada rumah sakit pemerintah di Semarang bahwa sebesar $56,2 \%$ mentoring pelaksanaan keselamatan pasien masih kurang baik, sementara di rumah sakit swasta Panti Waluya Sawahan Malang oleh Harus B.D (2015) dilaporkan data kejadian tidak diharapkan (KTD) 9 insiden (41\%), kejadian nyaris cedera (KNC) 6 insiden (27\%), kejadian potensial cedera (KPC) 5 insiden (23\%), kejadian tidak cedera (KTC) 2 insiden (9\%). Data insiden keselamatan pasien masih banyak ditemukan baik di rumah sakit pemerintah maupun swasta meskipun telah lulus akreditasi, sehingga dapat menimbulkan dampak negatif terhadap pelayanan kesehatan. 
Data insiden tersebut menunjukkan bahwa Indonesia belum memiliki sistem pencatatan kesalahan secara nasional. Pelaporan data tentang kejadian tidak diharapkan (KTD) dan kejadian nyaris cedera (KNC) belum banyak dilakukan oleh rumah sakit di Indonesia. Data tentang KTD dan KNC di Indonesia masih sulit ditemukan untuk dipublikasikan. Namun diperkirakan dampak kerugian akibat KTD dan KNC tersebut cukup besar. Dampak dari KTD dapat berupa cacat ringan, sedang hingga berat, bahkan dapat berakibat fatal dan kematian. Berdasarkan penelitian penelitian diatas bahwa budaya penerapan keselamatan pasien di rumah sakit masih bervariasi. Oleh karena itu perlu adanya peningkatan pada penerapan budaya keselamatan pasien di rumah sakit.

\section{Pembahasan}

Keselamatan pasien Rumah Sakit adalah suatu sistem Dimana rumah sakit membuat asuhan pasien lebih aman yang meliputi asesmen risiko, Identifikasi dan pengolahan hal yang berhubungan dengan risiko pasien, pelaporan dan analisis insiden, kemampuan belajar dari insiden dan tindak lanjutnya serta implementasi solusi untuk meminimalkan timbulnya risiko dan mencegah terjadinya cedera yang disebabkan oleh kesalahan akibat melaksanakan suatu tindakan atau tidak mengambil tindakan yang seharusnya diambil (Peraturan Menteri Kesehatan RI nomor 1691, 2011).

Budaya keselamatan pasien merupakan hal pokok dan mendasar dalam pelaksanaan keselamatan pasien di rumah sakit. Budaya keselamatan pasien merupakan salah satu faktor penting yang mempengaruhi keselamatan pasien. Budaya pasien yang baik akan membuat implementasi keselamatan pasien menjadi baik. Menurut Cahyono (2008) budaya keselamatan pasien merupakan pondasi keselamatan pasien. Membangun budaya keselamatan pasien merupakan kata kunci terwujudnya pelayanan yang bermutu dan aman. Setiap rumah sakit harus menjamin penerapan keselamatan pasien pada pelayanan kesehatan yang diberikan kepada pasien (Fleming \& Wentzel, 2008). Hal ini dikarenakan fokus pada budaya keselamatan pasien akan menghasilkan penerapan keselamatan pasien yang lebih baik dibanding jika hanya berfokus pada program keselamatan pasien saja (Eljadali, Dimassi, Jamal, jaafar, \& Hemadeh, 2011). Budaya keselamatan pasien sebagai pondasi dalam usaha penerapan keselamatan pasien yang merupakan prioritas utama dalam pemberian layanan kesehatan. Fondasi keselamatan pasien yang baik akan meningkatkan mutu pelayanan kesehatan khususnya asuhan keperawatan. 
Perawat dalam memberikan asuhan keperawatan kepada pasien harus menerapkan keselamatan pasien. Perawat harus melibatkan kognitif, afektif dan tindakan yang mengutamakan keselamatan pasien. Perawat dalam memberikan asuhan keperawatan harus dengan penuh kepedulian. Resepsi perawat untuk menjaga keselamatan pasien sangat berperan dalam pencegahan, pengendalian dan peningkatan keselamatan pasien. Pemberian layanan kesehatan berkontribusi terhadap terjadinya kesalahan yang mengancam keselamatan pasien khususnya perawat, pelayanan terlama (24 jam secara terus-menerus) dan sering berinteraksi pada pasien berdasarkan prosedur dan tindakan keperawatan. Hal ini dapat memberikan peluang yang besar untuk terjadi kesalahan dan keselamatan pasien. Selain itu kelelahan pada perawat merupakan faktor yang berkontribusi terjadinya kesalahan. Karakteristik perawat mempengaruhi pekerjaannya sehari-hari dan berpotensi terhadap kesalahan dalam keselamatan pasien.

Perawat dalam melaksanakan keselamatan pasien dipengaruhi oleh faktor internal dan eksternal. Faktor internal merupakan karakteristik perawat yang bersifat bawaan yang teridentifikasi berupa tingkat kecerdasan, tingkat emosional, dan pengalaman pribadi. Faktor eksternal yang mempengaruhi perilaku perawat adalah lingkungan, seperti pengaruh orang lain yang dianggap penting atau kepemimpinan, budaya dan sistem organisasi. Faktor ini sering menjadi faktor dominan yang mewarnai perilaku seseorang. Faktor eksternal berupa pengaruh orang lain juga dapat menimbulkan persepsi perawat terhadap pelaksanaan keselamatan pasien. Perilaku perawat dan tidak menjaga keselamatan pasien berkontribusi terhadap insiden keselamatan pasien. Perawat yang tidak memiliki kesadaran terhadap situasi yang cepat memburuk gagal Mengenali apa yang terjadi dan mengabaikan informasi klinik penting yang terjadi pada pasien dapat mengancam keselamatan pasien. Perilaku yang tidak aman, lupa, kurangnya perhatian, motivasi, kecerobohan dan kelelahan beresiko terjadinya kesalahan selanjutnya. Pengurangan kesalahan dapat dicapai dengan modifikasi perilaku. Keselamatan pasien merupakan hak pasien yang dijamin dalam UU Nomor 44 tahun 2009 tentang Rumah Sakit, untuk itu pihak rumah sakit perlu meminimalkan kesalahan-kesalahan yang mungkin terjadi dalam setiap tindakan yang dilakukan terhadap pasien di rumah sakit. Salah satunya upaya meminimalkan kejadian- kejadian tersebut adalah dengan pembentukan tim kesehatan pasien di rumah sakit yang bertugas menganalisis dan mengkaji kejadian- kejadian yang berhubungan dengan keselamatan pasien. 
Penerapan keselamatan pasien memungkinkan perawat mencegah terjadinya kesalahan kepada pasien saat memberikan layanan kesehatan di Rumah Sakit. Hal ini dapat meningkatkan rasa aman dan nyaman pasien yang dirawat di rumah sakit (Armellino, Griffin, \& Fitzpatrick, 2010). Penerapan budaya keselamatan pasien akan mendeteksi kesalahan yang akan dan telah terjadi (Fujita et al, 2013; Hamdan \& Saleem, 2013). Budaya keselamatan pasien tersebut akan meningkatkan kesadaran untuk mencegah error dan melaporkan jika ada kesalahan (Jeffs, law \& Baker, 2007). Hal ini dapat memperbaiki outcome yang dihasilkan oleh Rumah Sakit tersebut.

KKP-RS dalam panduan nasional keselamatan pasien Rumah Sakit membuat sistematika langkah penerapan keselamatan pasien rumah sakit yang terdiri dari tiga fase yaitu fase persiapan, fase pelaksanaan, dan fase evaluasi. Pada fase persiapan yaitu menetapkan kebijakan, rencana jangka pendek dan program tahunan keselamatan pasien rumah sakit. Pada fase pelaksanaan yaitu deklarasi gerakan keselamatan pasien, program 7 langkah keselamatan pasien, penerapan standar akreditasi keselamatan pasien, buat unit sebagai model pilot project, buat program program khusus terkait keselamatan pasien seperti program cuci tangan, dokter penanggung jawab pasien, pelaporan dan sebagainya, bentuk forum diskusi periodik untuk mengembangkan KPRS. Pada fase evaluasi yaitu itu evaluasi menyeluruh setahun sekali untuk memperbaiki program KPRS (Yasmi, 2018).

Mengacu pada hal tersebut maka Rumah Sakit harus merancang proses baru atau memperbaiki proses yang ada memonitor dan mengevaluasi kinerja melalui pengumpulan data, menganalisis secara intensif KTD dan melakukan perubahan untuk meningkatkan kinerja serta keselamatan pasien. Proses perancangan tersebut harus mengacu pada visi misi dan tujuan rumah sakit, kebutuhan pasien, petugas pelayanan kesehatan, kaidah klinis terkini, praktek bisnis yang sehat dan faktor-faktor lain yang berpotensi risiko bagi pasien sesuai dengan "Tujuh langkah keselamatan pasien Rumah Sakit" yaitu: (DepkesRI, 2008).

1. Bangun kesadaran akan nilai keselamatan pasien. Ciptakan kepemimpinan dan budaya yang terbuka dan adil.

2. Pimpin dan dukung staf anda. Bangunlah komitmen dan fokus kuat dan jelas tentang keselamatan pasien di rumah sakit. 
3. Integrasikan aktivitas pengelolaan risiko. Kembangkan sistem dan proses pengolahan risiko, serta Lakukan identifikasi dan asesmen hal yang berpotensial.

4. Kembangkan sistem pelaporan. Pastikan staf Anda agar dapat mudah dalam melaporkan kejadian atau insiden serta Rumah Sakit mengatur pelaporan kepada komite keselamatan pasien rumah sakit (KKPRS)

5. Libatkan dan berkomunikasi dengan pasien. Kembangkan cara-cara komunikasi yang terbuka dengan pasien

6. Belajar dan berbagi sebuah pengalaman tentang keselamatan pasien. Dorong staf anda untuk melakukan analisis Akar masalah untuk belajar bagaimana dan mengapa kejadian itu timbul

7. Mencegah cedera melalui implementasi sistem keselamatan pasien. Gunakan informasi yang ada tentang kejadian atau masalah untuk melakukan perubahan pada sistem pelayanan.

Ada beberapa hal yang berhubungan dengan upaya peningkatan penerapan budaya keselamatan pasien rumah sakit yaitu:

Ada hubungan kerjasama tim dengan budaya keselamatan pasien. Dalam melaksanakan asuhan keperawatan kepada pasien, Perawat akan selalu membutuhkan bantuan dari perawat maupun tenaga kesehatan yang lainnya, korelasi antara unit kerja/kerjasama dengan penerapan patient safety adalah bermakna, Kerjasama yang dilakukan di dalam unit kerja masing-masing. Kerjasama yang baik tentu akan menghasilkan penerapan budaya keselamatan pasien yang baik. Penerapan budaya keselamatan pasien yang adekuat harus ditunjang oleh seluruh unit di rumah sakit tersebut. Unit-unit ini diharapkan dapat bekerja sama membentuk suatu sistem kerja sehingga proses pelayanan kesehatan dapat berjalan dengan optimal. Terwujudnya pelayanan kesehatan yang bermutu dan aman tergantung pada kokohnya sistem yang dibangun dari unitunit yang ada di rumah sakit (Heriyati, 2019).

Ada hubungan komunikasi terhadap budaya keselamatan pasien, kegagalan komunikasi paling tinggi ditemui pada komunikasi lisan. Kerja sama pasien dapat ditingkatkan melalui komunikasi efektif, tepat waktu, akurat, lengkap, dan jelas. Komunikasi antara pemberi pelayanan harus ditingkatkan, komunikasi dalam pelayanan kesehatan terjalin antara semua tim yang terlibat dalam pengobatan dan perawatan pasien, kondisi kesehatan pasien yang menyangkut status 
kesehatan pasien yang membahayakan dan hasil pemeriksaan penunjang harus dikomunikasikan dengan lengkap dan tepat waktu (Heriyati, 2019).

Ada hubungan iklim kerja terhadap budaya keselamatan pasien. Perawat ataupun karyawan yang mempunyai iklim kerja yang baik akan meningkatkan budaya keselamatan pasien. Adanya iklim kerja yang baik memberi keyakinan bahwa pengecekan/pengukuran keselamatan sebagai tindakan pencegahan yang mujarab (Confidence in the efficacy of preventative (safety) measures) dan menjadi bagian penilaian kinerja karyawan atau perawat tersebut (Heriyati, 2019).

Ada hubungan no blaming culture terhadap budaya keselamatan pasien. Budaya yang menuduh, menyalahkan dan mengkritik ( accuse, blame, and criticze) yang masih banyak dipakai di berbagai organisasi Rumah Sakit dan tidak mendukung pengembangan program keselamatan pasien. Semua pihak bertanggung jawab menciptakan keselamatan pasien, kebiasaan saling menyalahkan dapat memungkinkan individu melaporkan dan mendiskusikan kejadian tidak diinginkan tanpa merasa takut akan hukuman serta memastikan setiap individu bertanggung jawab dalam pelaksanaan budaya keselamatan pasien. Tetap menjadi enggan untuk melaporkan kesalahan pelayanan kesehatan karena respon organisasi yang menyalahkan pelaku yang terlibat dalam insiden tersebut (Heriyati, 2019).

Ada hubungan sistem pelaporan insiden terhadap budaya keselamatan pasien. Dalam menciptakan budaya keselamatan pasien adalah pelaporan kejadian insiden/kondisi yang tidak diharapkan serta adanya sistem umpan balik, kondisi ini belum membudaya di instansi-instansi pelayanan kesehatan karena ada faktor ketakutan atau kekhawatiran atau bahkan menganggap insiden merupakan aib petugas kesehatan yang harus ditutupi. Budaya belajar dari kesalahan dan tidak melakukan pembelaan terhadap petugas yang melakukan kesalahan harus ditunjukkan oleh pimpinan. Informasi yang adekuat akan digunakan sebagai data untuk proses pembelajaran dalam meningkatkan upaya keselamatan pasien (Heriyati, 2019).

Ada hubungan pendidikan dan pelatihan terhadap budaya keselamatan pasien. Tingkat pengetahuan atau pendidikan tenaga medis khususnya perawat sangatlah penting dalam melaksanakan asuhan keperawatan. Upaya untuk menambahkan tingkat pengetahuan atau pendidikan perawat atau tenaga kesehatan yang lain yaitu melalui pelatihan atau seminar. Pelatihan dan seminar dapat bermanfaat untuk melakukan evaluasi terhadap program-program 
dan standar-standar termasuk standar asuhan keperawatan. Tingkat pengetahuan atau pendidikan yang tinggi akan mempengaruhi kinerja perawat atau tenaga kesehatan tersebut sehingga asuhan keperawatan akan terlaksana dengan baik dan kemungkinan terjadinya malpraktek atau kelalaian rendah. Hal ini terjadi karena perawat atau tenaga medis telah dibekali dengan pengetahuan tentang etika dan patient safety (Mudayana, 2014).

\section{Kesimpulan}

Dalam upaya peningkatan penerapan budaya keselamatan pasien terdapat ada hubungan kerjasama tim, komunikasi, iklim kerja, no blaming culture, pelaporan insiden, Pendidikan dan Pelatihan dengan budaya keselamatan pasien. Budaya keselamatan pasien akan tercipta apabila tenaga kesehatan memiliki pemimpin yang bersedia bekerjasama demi terlaksananya patient safety. Selain itu pengetahuan dan komunikasi di berpengaruh terhadap pelaksanaannya patient safety. Salah satu aspek yang penting dalam terlaksananya patient safety yaitu aspek etika. Etika sangatlah penting karena akan menyangkut tentang prosedur dalam melaksanakan asuhan keperawatan atau melaksanakan tugas dalam melayani kesehatan titik dalam pelayanan kesehatan maka tenaga medis harus selalu dengan kode etik dan hukum kesehatan. Hal ini untuk menghindari atau mengurangi praduga terjadinya malpraktik dan terjadinya kelalaian.

\section{Daftar Pustaka}

Buhari, B. (2019). Budaya Keselamtan Pasien Rumah Sakit Pemerintah dan Rumah Sakit Swasta Di Kota Jambi. Jurnal Aisyiyah Medika, 3 (1), 1-41.

Heriyati., Al-Hijrah, M, F., \& Masniati. (2019). Budaya Keselamatan Pasien Rumah Sakit Umum Daerah Majene. Jurnal Kesehatan, 2 (3), 194-205.

Iriviranty, A. (2015). Analisis Budaya Organisasi dan Budaya Keselamtan Pasien sebagai Langkah Pengembangan Keselamatan Pasien di RSIA Budi Kemuliaan. Jurnal Adminstasi Rumah Sakit, 1 (3), 196-203.

Juniarti, N, H., \& Mudayana, A, A. (2018). Penerapan Standar Keselamatan Pasien Di Rumah Sakit Umum Daerah Provinsi Nusa Tenggara Barat. Jurnal Kesehatan Poltekkes Ternate, 11 (2), 93-108. 
Mandriani, E., Hardisman., \& Yetti, H. (2019). Analisis Dimensi Budaya Keselamatan Pasien Oleh Petugas Kesehatan Di RSUD dr Rasidin Padang. Jurnal Kesehatan Andalas, 8 (1),131-137.

Mudayana, A, A. (2014). Peran Aspek Etika Tenaga Medis Dalam Penerapan Budaya Keselamatan Pasien Di Rumah Sakit. Supplemen Majalah Kedoktersn Andalas, 37 (1), 69-74.

Simamora, R. H., \& Fathi, A. (2019). The Influence Of Training Handover Based SBAR Communication For Improving Patients Safety. Indian journal of public health research \& development, 10(9), 1280-1285.

Siregar, R, A. (2016). Hubungan Perawat Dan Pasien: Implementasi Standar Keselamatan Pasien. Jurnal Hukum to-ra, 2 (1), 295-304.

Suci, W, P. (2018). Peningkatan Budaya Keselamatan Pasien Melalui Pemberdayaan Champion Keselamatan Pasien. JKH, 2 (2), 23-38.

Ultaria, T, D., Arso, S, P., \& Sriatmi, A. (2017). Gambaran Budaya Keselamatan Pasien di RS Roemani Muhammaddiyah Semarang. Jurnal Kesehatan Masyarakat, 5 (1), 118-125.

Wulandari, M, R., Yulia, S., \& Triwijayanti, R. (2019). Peningkatan Budaya Keselamtan Pasien Melalui Peningkatan Motivasi Perawat Dan Optimalisasi Peran Kepala Ruang. Jurnal Kepemimpinan dan Manajemen Keperawatan, 2 (2), 59-65.

Yasmi, Y., \& Thabrany, H. (2018). Faktor-Faktor Yang Berhubungan Dengan Budaya Keselamatan Pasien Di Rumah Sakit Karya Bhakti Pratiwi Bogor. Jurnal Administrasi Rumah Sakit, 4 (2), 98-107. 